\title{
Deep divisions complicate global environment meeting
}

\begin{abstract}
Washington. Representatives of 60 governments will gather in Beijing this weekend to discuss their disagreements about the structure and funding of an international agency set up to help poor countries tackle global environmental issues.
\end{abstract}

The Global Environment Facility (GEF) - an offshoot of the United Nations and the
During the pilot, the European countries promised $\$ 800$ million and the United States, Japan, Canada and Australia $\$ 400$ million for projects to be selected by each country. But none of the $\$ 150$ million pledged by the United States, for example, has been allocated, and European officials say that future participants will be required to make a more definite commitment.

GEF is expected to need $\$ 3-\$ 4$ billion over the next five years.

Although US President Bill Clinton is said to be keen to reverse the policies of his predecessor and to contribute to GEF, administration officials are refusing to do so until GEF meets a list of conditions that would open up the process. Congress has decreed that the $\$ 30$ million appropriated for GEF this year will

Reforesting Africa is one goal of GEF.

World Bank - is nearing the end of a threeyear pilot phase during which it has pledged more than $\$ 700$ million to support 113 projects, ranging from biodiversity conservation in Cameroon to the management of waste from ships in the Caribbean. At last year's Earth Summit in Brazil, it was agreed that the GEF - subject to certain reforms should also serve as the main vehicle to finance projects stemming from the treaties on biodiversity and climate change.

That role is, however, threatened by divisions between the United States and European countries on how to pay for GEF and between the rich and poor countries on how it should make its decisions. The prospects for resolving those differences at Beijing are not good, officials say, although some sort of agreement is expected before the pilot phase runs out in December.

At the top of the agenda at Beijing will be reform of the decision-making structure of GEF. The poor countries are seeking a system that gives one vote for each participant, the rich a system weighted according to a country's financial contribution. The conference will discuss a structure that will give each side an effective veto by requiring a 'double majority' - of both the number of countries and the amount of money contributed - but no decision is expected until after meetings in Washington in September and Geneva in December.

The other major item of discussion will be financing GEF after its pilot phase ends.
Sydney. Australia's largest research organization, the Commonwealth Scientific and Industrial Research Organisation (CSIRO), is dismantling the commercialization company it set up in the early 1980 s.

The company, known as Sirotech, will be reduced to a core of legal and patent specialists; project officers who supervised specific projects will be reassigned to the organization's far-flung laboratories.

The reorganization is not due to any particular dissatisfaction with Sirotech, formed as part of an effort to get closer to the industrial and agricultural sectors the CSIRO was set up to serve. Although Sirotech has not missed any major opportunities, it cannot claim any large-scale successes.

The company has assisted in a number of projects to commercialize the results of research at CSIRO, which has a total annual budget of A $\$ 670$ million (US\$478 million) and is Australia's largest employer of scientists. Those major projects include the Sirosmelt and related Isasmelt metal smelting process now being used to smelt copper at Mt Isa mines in the northern state of

had not been dealt with.

The chief criticism of GEF is that it is inheriting not only the secrecy and bureaucratic slowness of its administrative parent, the World Bank, but that it is also diverting the World Bank from environmental issues in its other programmes.

Environmental groups want the US government to demand more openness at the GEF before spending any money. But they say that it will be difficult for the United States to champion reform at Beijing when it has not contributed to GEF. They also say that the United States must explain exactly what it wants GEF to accomplish.

"We need a clearer picture of exactly what the US agenda is for reforming the Global Environment Facility", says Glenn Prickett of the Natural Resources Defense Council in Washington. "The US position doesn't exist yet."

European unhappiness with US policy is likely to surface at Beijing. "The United States has been incredibly active on the minutiae of GEF", says one European staffer at GEF, "but so far they haven't put in a bean." The attitude of the US delegation will determine if the mood will improve, with Prickett hoping for "a new tone" and a more productive relationship with the rest of the world.

The meeting will also examine ways in which non-governmental organizations (NGOs) in both donor and recipient countries can become involved in GEF's operations. An NGO meeting immediately before the main event will give these bodies a chance to be heard, and the conference will receive a report on how they could be more deeply involved.

Colin Macilwain

\section{Australia rethinks technology transfer}

Queensland and the exploitation of new simulation technology for the handling of air traffic.

However, CSIRO found that having a central company for an organization with 33 divisions spread all round Australia was far from ideal. A CSIRO spokesman said that companies interested in marketing a product preferred to deal directly with the scientist concerned rather than through a Sirotech project officer based elsewhere. CSIRO receives 30 per cent of its funding from nongovernment sources.

The hope is that moving the project officers physically closer to the scientists will bring both under the direct supervision of the organization's line managers, who are scientists. John Stocker, CSIRO's chief executive, said that is a goal of the organization's board.

The company has a staff of 45 and a budget of AS4 million a year. The details of who will move to the operational sites and how many will remain will be decided in negotiations now under way.

Mark Lawson 